Journal of Sustainable Development of Transport and Logistics

journal home page: http://jsdtl.sciview.net

\title{
The role of legal regulation and place of international organisations in transport companies' development at foreign market
}

\section{Oleh Lyashuk *, Valentyna Kuzmych ${ }^{* *}$, Viktoria Lototska ${ }^{* * *}$}

* Ternopil Ivan Pul'uj National Technical University,

56, Ruska str., Ternopil 46001, Ukraine

e-mail:oleglashuk@ukr.net

Dr., Professor, Department of automobiles

** State Road Transport Research Institute,

57 Peremohy Ave, Kyiv, 03113, Ukraine

e-mail: vkuzmich@insat.org.ua

Head of the scientific and methodological training and staff development of road transport

*** Ternopil Ivan Pul'uj National Technical University,

56, Ruska str., Ternopil 46001, Ukraine

e-mail:v.ozer4uk@yandex.ua

Senior Lecturer, Department of Transport Technology

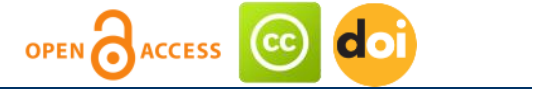

\section{Article history:}

Received: October, 2016

1st Revision: October, 2016

Accepted: November, 2016

\section{DOI:}

10.14254/jsdtl.2016.1-1.8

\begin{abstract}
The article deals with the analysis of the market of international trucking transport companies. The study is based on statistics and works of domestic and foreign scholars on the issue of current state and prospects of market development. Dedicated dynamics and structure of international trucking market, features of export, import and transit trucking. Identified the main priorities for the development and growth of the market.
\end{abstract}

Keywords: transport company, international market, trucking, cargo turnover, export, import, transit, transport corridors.

Corresponding author: Viktoria Lototska

E-mail:v.ozer4uk@yandex.ua

This open access article is distributed under a Creative Commons Attribution (CC-BY) 4.0 license. 


\section{Problem Stating}

Transport is a branch on industrial and service spheres joint.

Transport does not create any material values but provides transportation of people and freight develop relations between companies, branches and regions. Transport is called "circulatory system of the economy", because it is a necessary condition for the economy functioning.

The Ministry of Infrastructure of Ukraine and the Ukrainian International Road Carriers Association are representatives of international carriers of our country at the international level. One of the main tasks of the Ukrainian International Road Carriers Association is to represent interests of Association's participants and to advocate their rights at International Road Transport Union, as well as and to participate at meetings of the International Transport Forum. This gives an opportunity to advocate their positions and promote growing of quantity of licenses of European Ministers of Transport Conference and so on.

Road transport is a powerful sector of the Ukrainian economy, which serves practically all industries and all the population groups, promotes development of transport economic relations and population's life quality. Certainly, there are lots of problem in the sphere of international traffic, quality of the roads and quality of our transport means. There is a need to resolve these problems on legislative level because the further development of the branch of the Ukrainian economy depends of that.

\section{Analysis of the latest researches and publications}

In studying of the trucking companies functioning on the market of freight transportations were engaged such domestic and foreign scientists, as Golikov, \& Kazakova, 2002; Deineka, 2002; Demski, Hizhevskyy, Demski, \& Milosevic, 2002; Dykan, Kalinichenko, 2008; Dyachenko, 2002; Kotlobay, 2008; Kunda, 2010; Pushkar, \& Zhovtyak, 2013; Safonova, 2000; Tsanev, 2006; Chernous, 2009; Popovych, 2016; Shevchuk, 2016.

\section{Separation of parts of the general problem that have not yet been resolved}

Despite significant achievements of researchers, a more detailed analysis is necessary in international transportation market and prospects for Ukrainian trucking companies within it.

\section{The goal of article}

The main purpose of this article is to ground methodologically the using of Ukraine's legislation and development of a transport system to ensure reliable international freight transportations and place of Ukrainian trucking companies in it.

\section{Presenting of the main material}

In recent years, the role of international transportation has significantly increased, due to several advantages such as product delivery "door to door" in the shortest terms and in optimal amounts. In developed European countries, such as Austria, Belgium, Netherlands, Switzerland, Sweden, Finland, Italy incomings from transactions related to international freights transportation to the state budget are in total from 5 to $15 \%$. In this aspect we can note learning experience of the Netherlands especially, where developed transport infrastructure allowed to take a quarter of European transport market.

As international freight transportation statistics indicates, the share of Ukrainian carriers in this market is low, because of the presence of a large number of Russian, Belarusian carriers and the Baltic countries carriers, who quickly evaluated its perspective. Besides that, we should take into account an increasing competition from Poland, Czech Republic, Slovakia and Hungary carriers, which have become the European Union Members, and who also have advantageous geopolitical location. A significant advantage that EU membership gives to these countries is simplified custom passing, which saves time and therefore increases the efficiency of the fleet using.

Nearly 56.2 thousand carriers on the market of commercial traffic at this time are engaged in business, in their activity using more than154 thousands of vehicles, in general. After analyzing statistics on freight transportations for the 2012-2014 years, it may be concluded that in 2012 and 2013 we can notice the growth of transportations, and a small decline in 2014, that is due to the political situation in the country. Road transportations occupy the largest amount of all types of Ukrainian transport carryings, the second place is devoted to railway transport. Ships, boats and aircraft are almost at the same level during 14 years. The highest level of road transportations we can observe in 2007 and 2008, due to a sharp decline connected with the economic crisis in 2009. During the 2011 - 2013th, transportations were almost at the same level. In 2014 there is a decline connected with the political situation in the country. Road freight transportations took the first place 
in European countries, as well as in Ukraine; railways are at the second place. The total volume of transportations in the European Union grew by 1.6\% in 2013 in comparing to the year 2012 due to increasing of the internal traffic in Europe.

The system of permits is one of the most important elements of intergovernmental agreements on international motor traffic. The system of permits puts limits in a quantitative relation the entrance of foreign freight vehicles into the territory of the country, thus creating conditions for more equal participation of carriers at international carryings based on mutual benefits.

The system of permits sets the entry order of freight vehicles registered in other countries. You can enter if only you have permission. The main function of the permission is to allow crossing the border.

The procedure for determining kinds of permission documents, their distribution, issuance and usage by Ukrainian carriers while conducting transportation on the territory of foreign countries is assigned to the central executives body, related to transport supervision, which is the Ministry of Infrastructure of Ukraine, namely its Department of Road Transport (according to the Law of Ukraine "On Road Transport ".

A license for conducting international transportations by means of road transport is a document issued by the competent authorities of the Contracting parties to international carriers to enter, transit through the territory of the Contracting parties and accomplishing other types of transportations provided by law. The number of licenses per year is determined at meetings of the mixed commissions of the countries which conclude an agreement on road traffic.

Types of permits. There are single licenses and multiple licenses of the European Conference of Ministers of Transport.

Single licenses in accordance with the provisions of intergovernmental agreements can be of such types:

- Two-way license gives a the right to travel with passengers (load) or without them between a points located at the territory of Ukraine, and a point which is located at the territory of a foreign state, indicated at the license (at one direction and backwards);

- Transit license gives the right to travel with passengers (load) or without them through the territory of a state indicated at the license which is not a country of landing (loading) or drop-off (discharge) at one direction and backwards;

- Universal license gives the right to travel with passengers (load) or without license through transit and two-way traffic, at one direction and backwards;

- Certificate to/ from third parties gives the right to travel with a load from point located at the territory of the state, which is indicated at the license, to the third state or from the third party to the point located at the territory of a state that is indicated at the license (Kunda, 2010; Popovych, 2016; Shevchuk, 2016).

The licenses for conducting international freight transportations are listed in tables 1-3.

An important component of the development of international transportation is the legal and regulatory basis for accomplishment of process.

The sources of the legal regulation of international transportation of freights by means of road transport are as follows:

- Norms of domestic legislation;

- Bilateral intergovernmental agreements on international traffic;

- Multilateral conventions and agreements drawn up within the UN.

Major international agreements related to transport developed by ITC UN ECE:

1. Convention on Road Traffic $(1949,1968)$;

2. "Green Card" system of obligatory civil liability insurance of owners of vehicles for caused damage (1953);

3. Convention on the Contract for the International Carriage of Goods by Road (CMR, 1956);

4. European Agreement concerning the International Carriage of Dangerous Goods by Road (ADR, 1957);

5. Agreement concerning the Adoption of Uniform Technical Prescriptions for Wheeled Vehicles, Equipment and Parts which can be fitted and/or be used on Wheeled Vehicles and the Conditions for Reciprocal Recognition of Approvals granted on the Basis of these Prescriptions $(1958,1995)$.

6. The Convention on International Transport of Goods Under Cover of TIR Carnets $(1959,1975)$;

7. Convention on road signs and signals (1968);

8. The European Agreement concerning the Work of Crews of Vehicles engaged in International Road Transport (1970).

9. Agreement on the International Carriage of Perishable Foodstuffs and on the Special Equipment to be Used for such Carriage (ATP, 1970)

10. Agreement concerning the Adoption of Uniform Conditions for Periodical Technical Inspections of Wheeled Vehicles and the Reciprocal Recognition of Such Inspection (1997);

11. European Agreement on Main International Traffic Arteries;

12. Convention about agreement on international road transportation of passengers and freights. 


\begin{tabular}{|c|c|c|}
\hline \begin{tabular}{c} 
Table 1. Basic quota of ECMT license of for Ukrainian carriers according to the years \\
\hline Year
\end{tabular} & Basic quota, piece & Total amount, piece \\
\hline 2011 & 237 & 2270 \\
\hline 2012 & 324 & 2296 \\
\hline 2013 & 337 & 3300 \\
\hline 2014 & 354 & 3452 \\
\hline 2015 & 370 & 3455 \\
\hline 216 & 370 & \\
\hline
\end{tabular}

The set of transport production systems, taking into consideration the legal and economic factors, make up a single integrated transport system. The system has to meet the population's and societal production's needs in transportation while possessing to have extensive infrastructure for providing the whole range of transport services, including warehousing and technological preparation of freights for transportation, in order to ensure efficient and reliable foreign economic relations of Ukraine (Demski, Hizhevskyy, Demski, \& Milosevic, 2002).

\begin{tabular}{|c|c|}
\begin{tabular}{|c|} 
Table 2. Total number of license (annual quota) for a trip to a foreign country for Ukrainian carriers \\
Year
\end{tabular} \\
\hline 2006 & 438,0 thou. \\
\hline 2007 & 538,7 thou. \\
\hline 2008 & 619,2 thou. \\
\hline 2009 & 649,6 thou. \\
\hline 2010 & 680,1 thou. \\
\hline 2011 & 731,1 thou. \\
\hline 2012 & 741,2 thou. \\
\hline 2013 & 785,6 thou. \\
\hline 2014 & 806,0 thou. \\
\hline 2015 & 799,9 thou. \\
\hline
\end{tabular}

\begin{tabular}{|c|c|c|c|}
\hline \multirow[t]{2}{*}{ State } & \multicolumn{2}{|c|}{ Quota } & \multirow[t]{2}{*}{ Quota's increasing } \\
\hline & 2011 & 2015 & \\
\hline Austria & 11950 & 13150 & 1200 \\
\hline Belgium & 14000 & 14500 & 500 \\
\hline Belarus & 47000 & 52500 & 5500 \\
\hline Bulgaria & 17600 & 23900 & 6300 \\
\hline Bosnia and Herzegovina & 300 & 350 & 50 \\
\hline Armenia & 1900 & 2600 & 700 \\
\hline Greece & 2365 & 3765 & 1400 \\
\hline Georgia & 4000 & 9100 & 5100 \\
\hline Denmark & 3170 & 4070 & 900 \\
\hline Estonia & 4600 & 8030 & 3430 \\
\hline Kazakhstan & 6850 & 10250 & 3400 \\
\hline Kirghizia & 600 & 1300 & 700 \\
\hline Latvia & 6600 & 10100 & 3500 \\
\hline Lithuania & 10450 & 17250 & 6800 \\
\hline Macedonia & 1865 & 1965 & 100 \\
\hline Norway & 300 & 625 & 325 \\
\hline Russia & 35000 & 48500 & 13500 \\
\hline Romania & 21600 & 22700 & 1100 \\
\hline Slovakia & 29600 & 37700 & 8100 \\
\hline Slovenia & 17550 & 19950 & 2400 \\
\hline Tadzhikistan & 170 & 650 & 480 \\
\hline Turkey & 23100 & 28000 & 4900 \\
\hline Turkmenistan & 0 & 1500 & 1500 \\
\hline Uzbekistan & 280 & 2000 & 1720 \\
\hline Finland & 7650 & 9700 & 2050 \\
\hline Croatia & 1250 & 1350 & 100 \\
\hline Czech Republic & 14300 & 17900 & 3600 \\
\hline
\end{tabular}




\begin{tabular}{|l|l|l|r} 
Total amount & 268185 & 363405 & 79355
\end{tabular}

Within this context, it is important to consider the functions connected with the operational activities of vehicles, as follows:

- Coordination of, activity of enterprises, institutions and organisations of automobile, aviation, railway, marine and river transport, road facilities and also of their associations;

- Preparing and directing of rolling stock (vehicles) in accordance with the transportation plans and concluded agreements;

- Preparation and coordination of the schedule of the vehicle movement;

- Provision of the development of vehicle repair facilities and rolling stock, and implementation in practice of modern automatic equipment, automatic remote controls, communications, energy supply devices and computer aids;

- Development and introduction of new routes of freight and passenger traffic at domestic and international traffic;

- Establishing of technical requirements for new types of rolling stock and tools, forming of orders for industry and monitoring of their implementation;

- Purchasing of new rolling stock and containers, ensuring of their major overhaul and modernization.

In addition, it should be considered the functions connected with the legal support of the transport system activity, such as:

- Development and approving in accordance with established procedure the rules of carrying freights, technical conditions of loading and fixing of cargos, rules of transportation of passengers also, cargo and mail, traffic rules, rules of service, other regulations associated with norms of sanitary condition and hygiene on the transport, safety of the vehicle, occupational safety and fire safety, environmental protection, certification and technical operation of rolling stock, the rules of people behaviour at transport and also people safety;

- Approval of enterprises' statutes, conclusion and termination of contracts with business leaders, preparation and signing of contracts;

- Participation in the design and development of international agreements, representation of interests of Ukrainian transport in international organisations; according to the Law of Ukraine "On licensing certain types of economic activity" dated 1 June 2000. Provision of licensing activity about provision of services of passenger and cargo transportation on all modes of transport.

Organisation of international road transport of goods and passengers is regulated by regulatory documents, which relate to the following groups:

- Requirements for vehicles admitted to international road transport;

- Rules, organisation and safety of movement of vehicles on highways;

- Requirements for drivers of vehicles engaged in international road transport, and organisation of their work;

- Conditions of performance of international road transport operations; rights, duties and responsibilities of the parties;

- The rules of trans-border and customs control;

- Taxation of international road transport operations and vehicles involved in that.

The international regulatory documents are developed by national and international organisations, both governmental and non-governmental. The governmental organisations are created by conclusion of intergovernmental agreements; and the non-governmental ones are created voluntarily, e.g. by national associations' agreeing.

Some of the most important government organizations are as follows:

- Inland Transport Committee of the Economic Commission for Europe of the United Nations (ITC UN/ECE);

- Directorate of Transport of the European Commission; International Transport Forum.

Among the non-governmental organizations are:

- International Road Transport Union (IRU-IRU);

- International Federation of Freight Forwarders Associations (FIATA-FIATA);

- National associations and unions (Kunda, 2010).

Conclusions and suggestions

Having analyzed the market of international road freight transportations and existing programs of transport development (Tsanev, 2006; Chernous, 2009; Popovych, 2016), we can identify priority actions about growth of market:

1. The implementation of penalty for freight cars to compensate the damage caused to roads.

2. Increased training of drivers (definition of educational programs to improve the skills of managers and specialists in road transport).

3. Improving the procedure for monitoring the use of tachographs. 
4. Separation of powers of central and local authorities in the management of roads, including through the transfer of local roads under the control of regional state administrations to the common property of local communities and others.

5. Strengthening the control of roads and settlement of legal relations while carrying.

6. Resolving the issue of access to the market of automobile carriers (carrier certification).

7. Ensuring environmental safety, compliance with environmental standards while conducting activities in the field of transport.

8. Inducing of the development of energy saving and environmentally friendly transport types.

9. Creating a network of logistics centres.

10. The reduced hours required for the handling of goods at checkpoints across the state border.

11. To ensure the development of intermodal transport.

12. Organisational and legal support of expansion of the motor carriers and creation of a network of integrated trucking companies.

13. To ensure the development of export of transport services, efficient use of transit potential, improving the competitiveness of domestic transport in the international transport market and so on.

Much attention it should be paid to the cooperation of Ukraine with foreign countries, establishing links in the form of multilateral conventions and agreements. It is important to ensure the law enforcement by carriers.

\section{Appendix A. Supplementary material}

Supplementary data associated with this article can be found, in the online version, at http://jsdtl.sciview.net

\section{Funding}

The authors received no direct funding for this research.

\section{Citation information}

Lyashuk, O., Kuzmych, V., \& Lototska, V. (2016). The role of legal regulation and place of international organisations in transport companies' development at foreign market. Journal of Sustainable Development of Transport and Logistics, 1(1), 49-55. doi: 10.14254/jsdtl.2016.1-1.8.

\section{References}

Chernous, A. I. (2009). Towards sustainable road transport system of the region. (Doctoral dissertation). Institute of economic and legal research of the National Academy of Sciences of Ukraine, Donetsk. (in Ukrainian).

Deineka, A. G. (2002). Strategic management in railway transport. Bulletin of Kharkov National University V. N. Karazin, Economic series, 64-65. (in Ukrainian).

Demski, E. F., Hizhevskyy, V. K., Demski, C. E., \& Milosevic, A.V. (2002). Transport Law Ukraine. Kyiv, Ukraine: Inter Yurinkom, 242-247. (in Ukrainian).

Dyachenko, T. A. (2002). Determination of competitiveness of the motor transportation enterprises and the strategy of its improvement. (Doctoral dissertation). National Aviation University, Kyiv, Ukraine. (in Ukrainian).

Dykan, V., Kalinichenko, L. (2008). The role of the investment-innovation potential of enterprises in accelerating the integration of national transport system into the European. Journal of transport economics and industry, 23, 58-64. (in Ukrainian).

Export, import and transit cargoes in Ukraine : Statistical Bulletin. (2016). Retrieved from: http://ukrstat.gov.ua/.

Golikov, A., \& Kazakova, N. (2002). World economy: industrial structure, geography, modern trends. Karazin KhNU, Kyuv, Ukraine: KNU. (in Ukrainian).

Kotlobay, M. S. (2008). Merchant shipping of Ukraine: problems and prospects of development. Odesa, Ukraine: BREED of NAS of Ukraine. (in Ukrainian).

Kunda, N. (2010). Textbook for students of a direction "Transport technologies" in higher education institutions. Kyiv, Ukraine: Publishing House "Slovo". (in Ukrainian).

Official website of the Ministry of infrastructure of Ukraine. (2016). Retrieved from: http://www.mtu.gov.ua/.

Popovych, P. V. (2016). Analitychni tehnologii v zabezpechenni ekonomichnoi efektyvnosti logistychnyh system. Visnyk HNTUSG, 169, 223-225. (in Ukrainian). 
Popovych, P.V. (2016). Ekonomichni aspekty vykorystannja poslug 3PL operatoriv vitchyznjanymy pidpryjemstvamy. Naukovyj zhurnal. Luckyj NTU, 2, 125-129. (in Ukrainian).

Pushkar, T. A., \& Zhovtyak, G. A. (2013). Current trends and prospects of development of road transport in the Eastern regions of Ukraine. Economics and State, 8, 56-59. (in Ukrainian).

Safonova, N. A. (2000). Organizational-economic methods of increase of competitiveness of transport enterprise. (Doctoral dissertation). Saint-Petersburg State University of Water Communications, SPb., Russia. (in Russian).

Shevchuk, O.S. (2016). Vplyv pokaznykiv efektyvnosti na bezpeku ruhu vulychno-dorozhnymy merezhamy. Visnyk HNTUSG, 169, 205-209. (in Ukrainian).

Transport and communications of Ukraine: Statistical Yearbook. (2016). Retrieved from: http://ukrstat.gov.ua/.

Transport strategy of Ukraine for the period till 2020. (2016). Retrieved from: http://search.ligazakon.ua/__doc2.nsf/link1/KR102174.html. (in Ukrainian).

Trucking. Freight.Price statistics. (2016). Retrieved from: http://della.com.ua/.

Tsanev, I. A. (2006). Organizational and economic aspects of security, minimize the risks of international road transport of foreign trade goods. (Doctoral dissertation). Moscow, Russia: WGE. (in Russian).

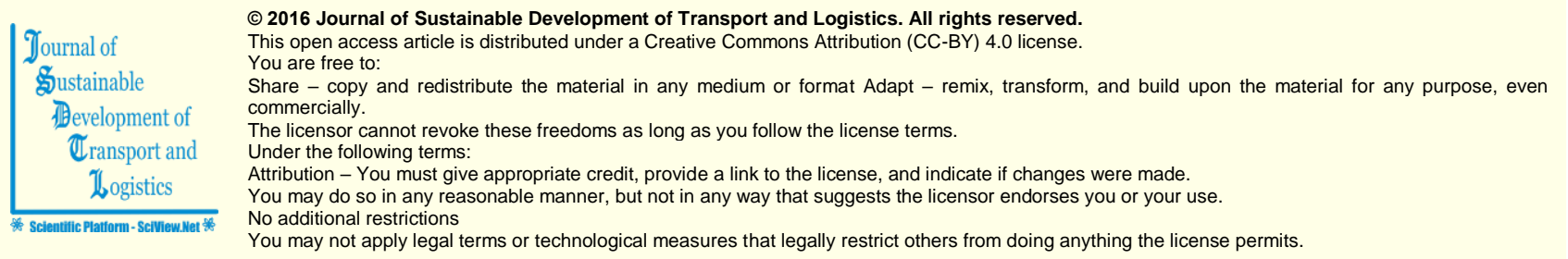

Journal of Sustainable Development of Transport and Logistics (ISSN: 2520-2979) is published by Scientific Publishing House "CSR", Poland, EU and Scientific Publishing House "SciView", Ukraine

Publishing with JSDTL ensures:

- Immediate, universal access to your article on publication

- High visibility and discoverability via the JSDTL website

- Rapid publication

- Guaranteed legacy preservation of your article

- Discounts and waivers for authors in developing regions

Submit your manuscript to a JSDTL at http://jsdtl.sciview.net/ or submit.jsdtl@sciview.ne 